\title{
Biomedical waste generation and management during COVID-19 pandemic in India: challenges and possible management strategies
}

\author{
Ashish Dehal $^{1,2} \cdot$ Atul Narayan Vaidya ${ }^{1} \cdot$ Asirvatham Ramesh Kumar $^{1,2}$ (D) \\ Received: 16 July 2021 / Accepted: 22 September 2021 / Published online: 7 October 2021 \\ (C) The Author(s), under exclusive licence to Springer-Verlag GmbH Germany, part of Springer Nature 2021
}

\begin{abstract}
The COVID-19 pandemic has resulted in the massive generation of biomedical waste (BMW) and plastic waste (PW). This sudden spike in BMW and PW has created challenges to the existing waste management infrastructure, especially in developing countries. Safe disposal of PW and BMW is essential; otherwise, this virus will lead to a waste pandemic. This paper reviews the generation of BMW and PW before and during the COVID-19 pandemic, the regulatory framework for BMW management, policy interventions for COVID-19-based BMW (C-BMW), the capacity of BMW treatment and disposal facilities to cope with the challenges, possible management strategies, and perspectives in the Indian context. This study indicated that policy intervention helped minimize the general waste treated as C-BMW, especially during the second pandemic. Inadequacy of common BMW treatment facilities' (CBMWTFs) capacity to cope with the BMW daily generation was observed in some states resulting in compromised treatment conditions. Suggestions for better management of BMW and PW include decontamination of used personal protective equipment (PPEs) and recycling, alternate materials for PPEs, segregation strategies, and use of BMW for coprocessing in cement kilns. All upcoming CBMWTFs should be equipped with higher capacity and efficient incinerators for the sound management of BMW. Post-pandemic monitoring of environmental compartments is imperative to assess the possible impacts of pandemic waste.
\end{abstract}

Keywords Biomedical waste $\cdot$ Common biomedical waste incineration facility $\cdot$ COVID-19 pandemic $\cdot$ Municipal solid waste $\cdot$ Personal protective equipment $\cdot$ Policy intervention $\cdot$ Single-use plastics

\section{Introduction}

It is beyond the wildest imagination; the whole world would be afflicted and stranded by a virus of size 50 to $200-\mathrm{nm}$ diameter, the SARS-CoV2 (Ramteke and Sahu 2020). The COVID-19 disease outbreak has generated a worldwide pandemic in economic, social, and environmental repercussions (Ikram et al. 2020; Singh et al. 2020a; Rayani et al. 2021; Yousefi et al. 2021). The virus has led to more than 189 million (M) cases worldwide and $4 \mathrm{M}$ deaths up to 15 th

Responsible Editor: Lotfi Aleya

Asirvatham Ramesh Kumar

ar_kumar@neeri.res.in

1 Chemical and Hazardous Waste Management Division, CSIR-National Environmental Engineering Research Institute, Nagpur 440020, India

2 Academy of Scientific and Innovative Research (AcSIR), Ghaziabad 201002, India
July 2021 (worldometer 2021). India stands at the 2nd position in the total number of COVID patients after the USA. In the present situation, the growth rate of COVID cases in India is the highest among all countries. The total number of confirmed cases in India was more than $31 \mathrm{M}$, and $0.4 \mathrm{M}$ deaths were reported till 15th July 2021 (worldometer 2021). In this pandemic situation, public health safety has become the priority of all governments.

Several countries have imposed lockdowns and curfews to safeguard the public from this novel virus (Kulkarni and Anantharama 2020; Irfan et al. 2021). The government of India introduced a countrywide lockdown from 25 th March 2020 as a critical move to combat the transmission of the COVID-19 virus. The first phase of lockdown lasted for 21 days. The increase in COVID-19 patients in India further led to the 2nd, 3rd, and 4th phases of lockdown, which extended until 30th May 2020 (Gangwar and Ray 2021).

The Government of India (GoI) issued new guidelines in June 2020, which enabled the reopening of commercial establishments, resumption of public transport, and various other 
activities to improve the economy (GoI, https://www.mha. gov.in/). The first phase (1st June-30th June) of reopening was termed "Unlock 1.0". In this phase, earlier lockdown restrictions need to be imposed in containment zones only, while some activities were allowed in other zones in a phased manner. According to these guidelines, large gatherings were prohibited. In all places, night curfews were in effect from 9 p.m. to 5 a.m., and state administrations were given authority to impose appropriate restrictions on all activities.

Similarly, unlock guidelines 2.0, 3.0, 4.0, 5.0, and 6.0 were issued with relaxation to various activities (GoI, https://www.mha.gov.in/). The first wave of COVID-19 in India was reported from January 2020 to February 2021. The peak of the first wave was observed in September 2020, with more than $1 \mathrm{M}$ active cases on 18th September 2020. The decline in the number of active cases in India was reported till February 2021. With the surge of the 2nd wave (February 2021 onwards), many states in India re-introduced the lockdowns. The peak of the 2nd wave was observed in May 2021, with more than 3.7 M active cases on 9th May 2021.

Online purchasing of consumer goods has become the preferred shopping mode (Rume and Islam 2020; Tabish et al. 2020; Irfan et al. 2021). The online way has also ensured the survival of services like retailing, catering which experienced significant losses due to lockdown at the pandemic's beginning (Liu et al. 2021). In this situation, plastic packaging has become a necessity for delivering goods. Single-use plastics (SUPs) have been extensively used for packaging due to economic and safety reasons (Liu et al. 2021; Parashar and Hait 2021).

Even before the emergence and dissemination of COVID19, many developing countries were under stress for managing biomedical waste (BMW) and plastic waste (PW) (Kulkarni and Anantharama 2020; Nzediegwu and Chang 2020). Copious use of medical technologies in hospitals and safety measures to stop the dissemination of the COVID-19 have led to tremendous increase in BMW generation. The sharp increase in personal protective equipment (PPEs), such as aprons, boots, face shields, gloves, goggles, masks, sanitizers, and other medical gears, including bandages, plastic containers, syringes, testing kits, tissues (shown in Figure 1) have drastically altered the BMW composition (Das et al. 2021a, b; Praveena and Aris 2021). Thus, the pandemic generated more pressure on the existing waste management system (Benson et al. 2021; Haque et al. 2021; Parashar and Hait 2021; Roy and Chaube 2021). The PPEs mainly consist of polymers such as low-density polyethylene (LDPE), polypropylene (PP), polyurethane (PU), polyvinyl chloride (PVC), and polycarbonate (PC). In contrast, packaging materials primarily consist of high-density polyethylene (HDPE), LDPE, polystyrene (PS), and polyethylene terephthalate (PET). Among these, PET and HDPE are widely recyclable polymers, and the rest are difficult to recycle or rarely recycled (Klemeš et al. 2020; Parashar and Hait 2021; Silva et al. 2021). The sharp rise of waste generation has disrupted even the most reputed global waste management facilities (Thind et al. 2021).

Plastics have driven scientific and technical advances in every field due to their flexibility, affordability, and durability. Plastic incorporates superb versatility, strength-to-weight ratio, water resistance, and insulating properties (Chen et al. 2020; Klemeš et al. 2020). Due to these characteristics, plastics are indispensable in the healthcare system, mainly for single-use diagnostic kits and devices. India generates about $9200 \mathrm{t} /$ day of PW, with a total generation of more than 3.3 million t per year (CPCB 2019a). The major PW-generating Indian states are Maharashtra, Tamil Nadu, Gujarat, and West Bengal. To check the growing PW generation, 22 states/union territories (UTs) of India have completely banned, and seven states have partially banned SUP carry bags (CPCB 2019a). But now, the spread of COVID-19 has become an obstacle to implement the ban on SUPs. This is seen as a compromise of the policy during the pandemic as human health is most important than anything else. Contrary to the common belief that plastic is not environment friendly, these SUPs have saved millions from contracting the infection. However, it is pretty common to see the littering of used PPEs due to negligence on the part of individuals that causes harm to the environment and human health (Rowan and Laffey 2021). The surge in the BMW generation during the pandemic is inevitable; however, lessons should be learned to deal with any such outbreak that increases waste in the future. The objectives of this article are to review the regulatory framework, institutional capacity, and the status of BMW management before and during the pandemic in India. Perspectives on the effective management of BMW during any such future events are also discussed. We used BMW data published by the regulatory agency Central Pollution Control Board (CPCB), advisories issued by the Government of India, in addition to keyword searches made in Scopus and Web of Science databases. To the best of our knowledge, this is the first article, which comprehensively reviews the regulatory framework, C-MBW generation vis-à-vis the treatment capacity of various states of India.

\section{Healthcare/hospital waste composition}

Health care waste $(\mathrm{HCW})$ includes all the waste generated by medical facilities. It comprises waste produced during testing, treatment, or vaccination of humans or animals. The quantity of general (non-hazardous) waste is $70-80 \%$ of total waste generated by health care facilities (HCFs) (WHO 2018; Das 


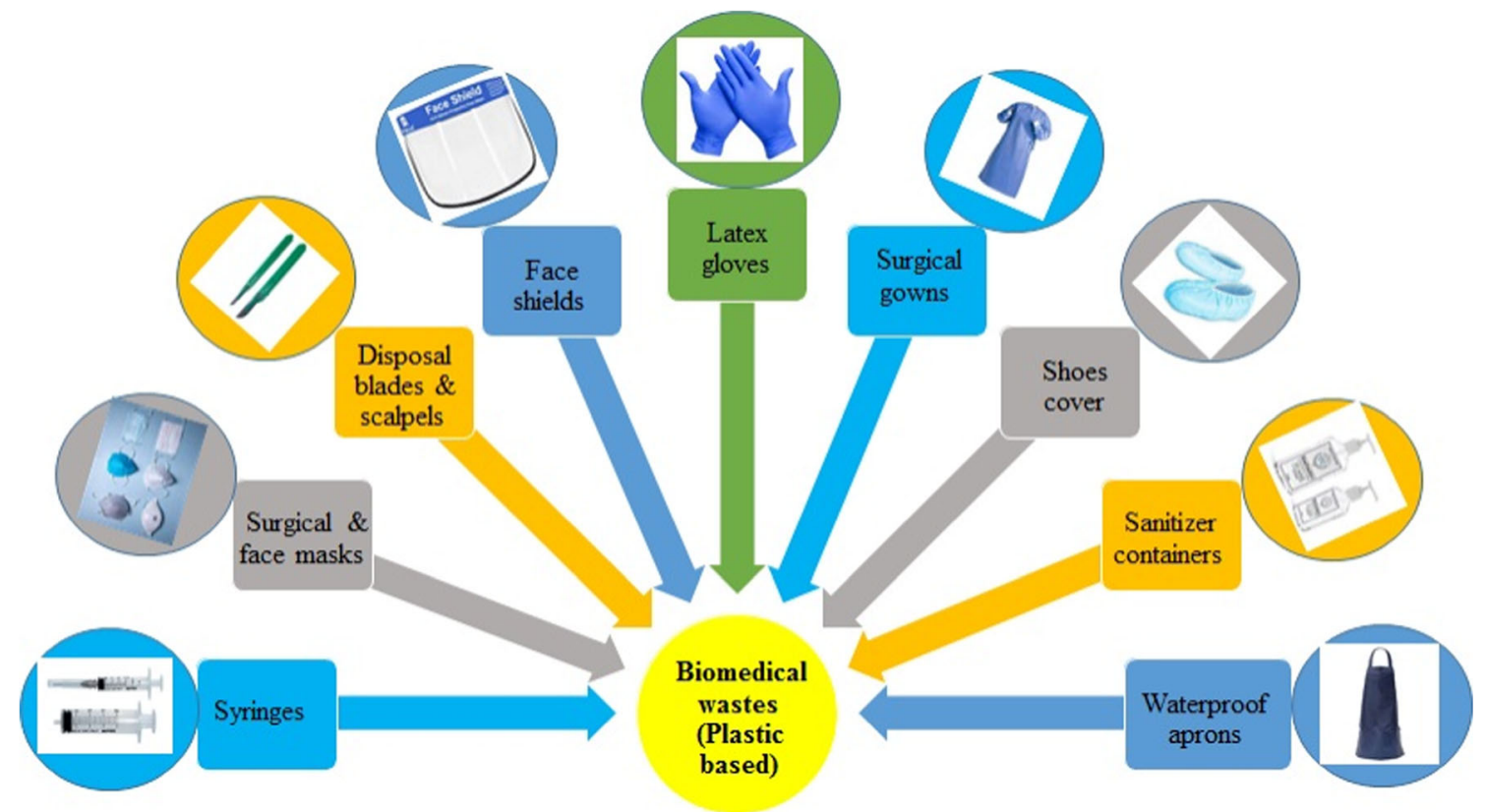

Fig. 1 BMW generation during COVID-19

et al. 2021b). Figure 2 shows the composition of HCW/ hospital waste (CPCB 2016a; Das et al. 2021b). BMW comprises the waste generated during the diagnosis and treatment of patients, excluding the general waste. Typical BMW generators are HCFs, blood banks, clinics, hospitals, nursing homes, research institutions, treatment units, etc.

According to a WHO report, $\mathrm{HCW}$ in developing countries is often not adequately segregated, thereby making the actual amount of BMW much higher (WHO 2018; Nzediegwu and
Chang 2020). In India, BMW is managed according to BMW Management Rules, 2016 (CPCB 2016a).

\section{BMW generation scenario in India before COVID-19 outbreak}

India generates about 619 t/day of BMW. Figures 3 and 4 show the state/UT wise generation of BMW for the year

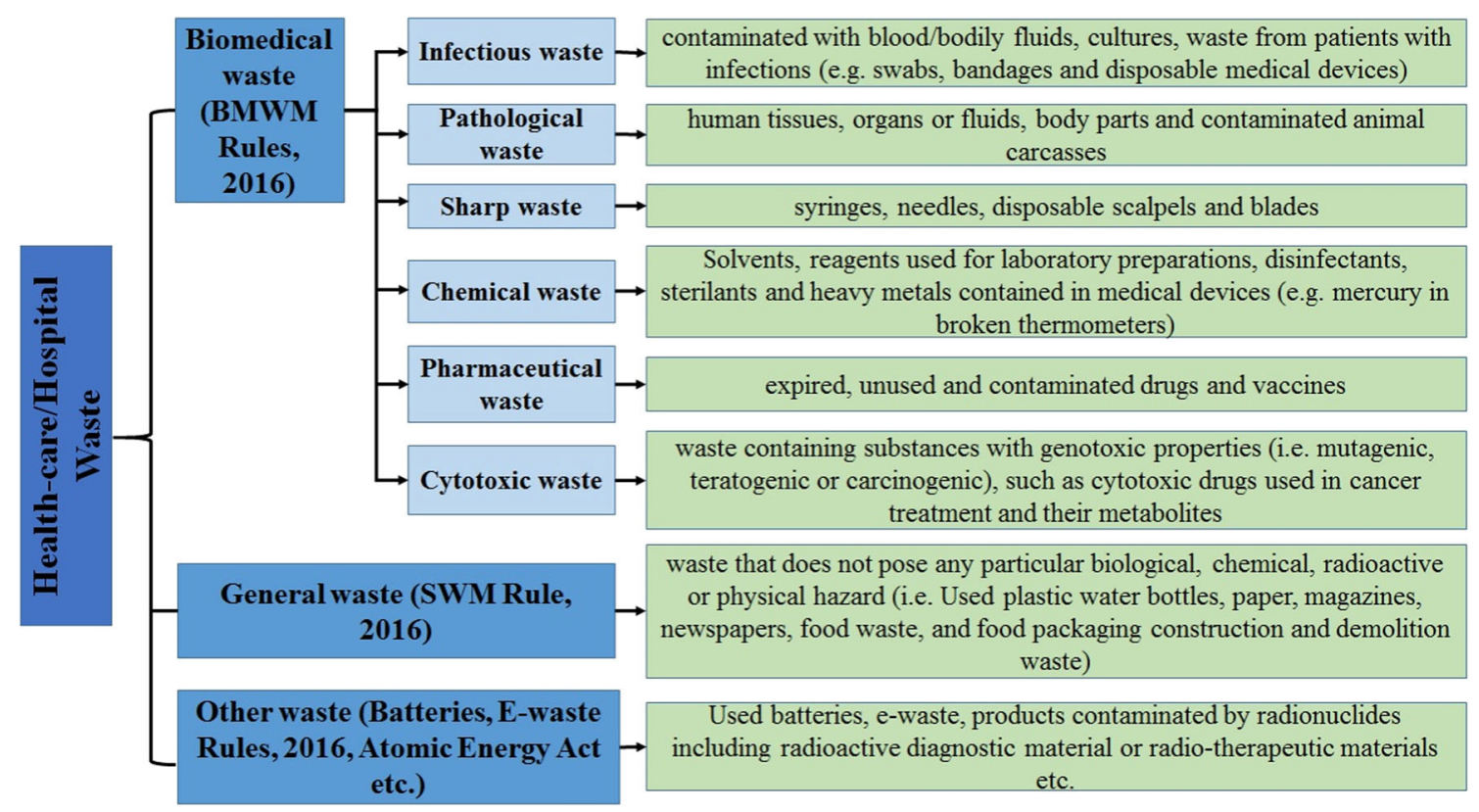

Fig. 2 Composition of HCF/hospital waste 
Fig. 3 BMW generation of different states/UTs in 2019

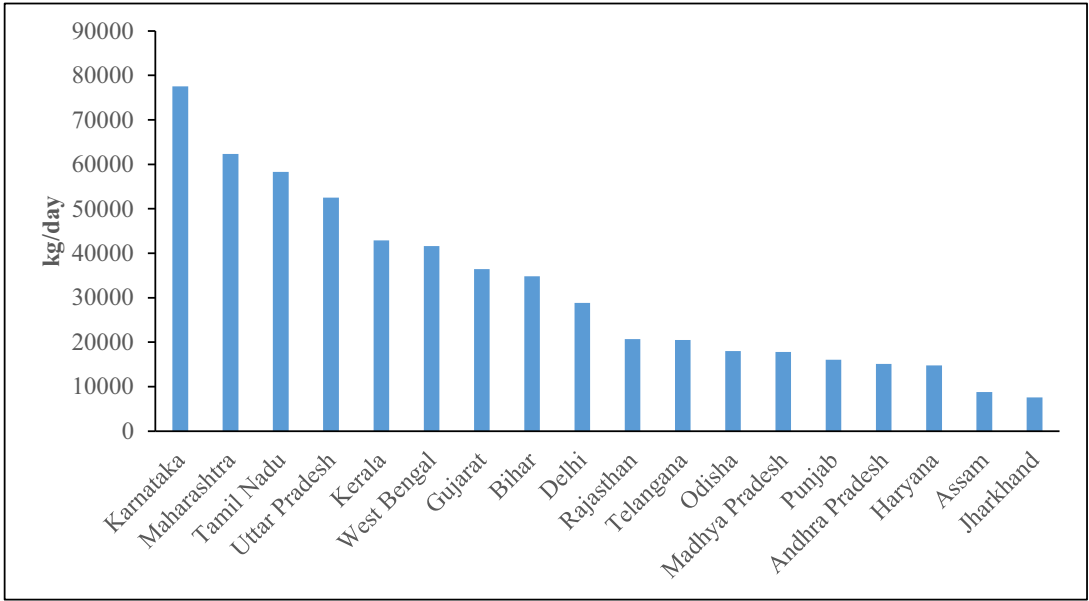

2019. The top five states that generated $47 \%$ of BMW were Karnataka, Maharashtra, Tamil Nadu, Uttar Pradesh, and Kerala. Among all states, Karnataka generated the highest BMW, accounting for $77.5 \mathrm{t} / \mathrm{day}$, and Arunachal Pradesh generated the lowest quantity, 0.4 t/day. Among all UTs, Delhi generated the highest BMW, i.e., $28.8 \mathrm{t} /$ day, and Lakshadweep generated the lowest quantity of BMW, $0.1 \mathrm{t}$ / day (CPCB 2019b).

\section{Regulatory framework of BMW management}

The BMW Management Rules, 2016 is the comphrehensive regulatory framework followed by India (CPCB 2016a). At HCFs, BMW is segregated into yellow, red, blue, and white categories of waste. The yellow category is also called infectious waste or incinerable waste. Different treatment procedures are adopted for the four categories of wastes. Figure 5 shows the treatment techniques and the disposal methods adopted to the four categories of BMW (CPCB 2016a, b, c).

\section{Incinerators in common BMW treatment facilities}

Incineration of medical waste is the most common treatment method adopted in several countries. Available incineration technologies include pyrolytic chamber/modular, rotary kiln, and fluidized bed incinerators. The selection of an appropriate incineration technology depends on factors such as calorific value of waste, moisture content, volume, composition, and cost factor. For more details, the reader may refer relevant literature (UNEP 2012). In India, dual chamber modular incinerators, which operate under the "controlled air" principle, are installed in all common BMW treatment facilities (CBMWTFs). It is economical compared to other types; however, it has the limitation of incineration capacity. All incineration technologies
Fig. 4 BMW generation of different states/UTs in 2019

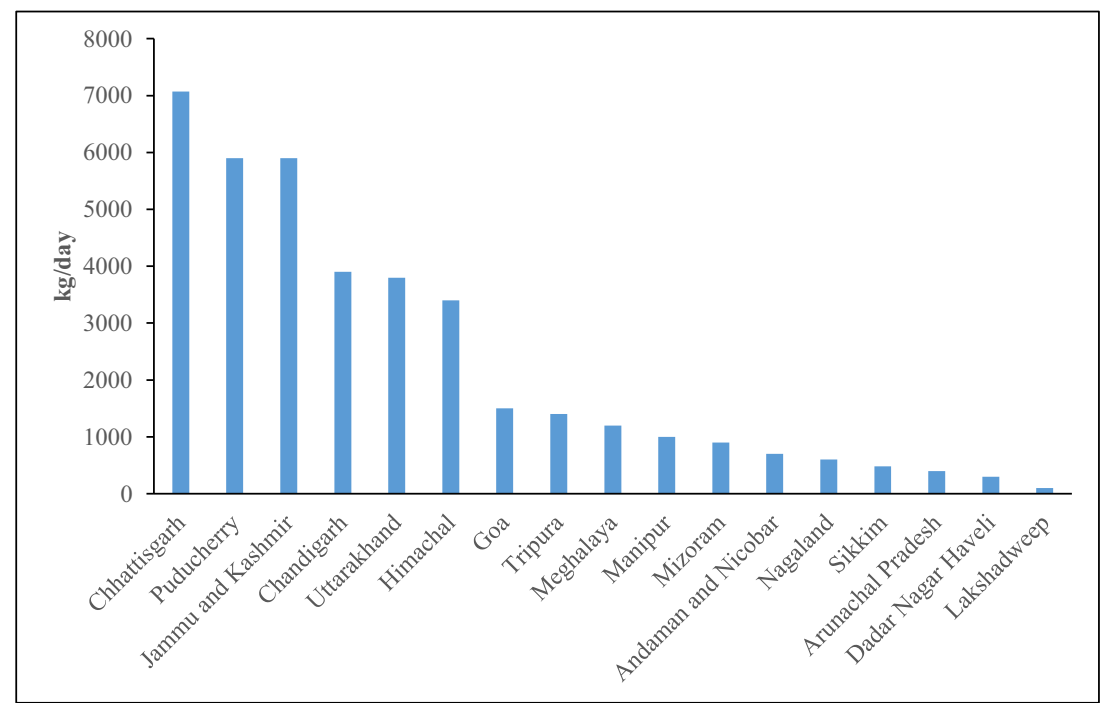




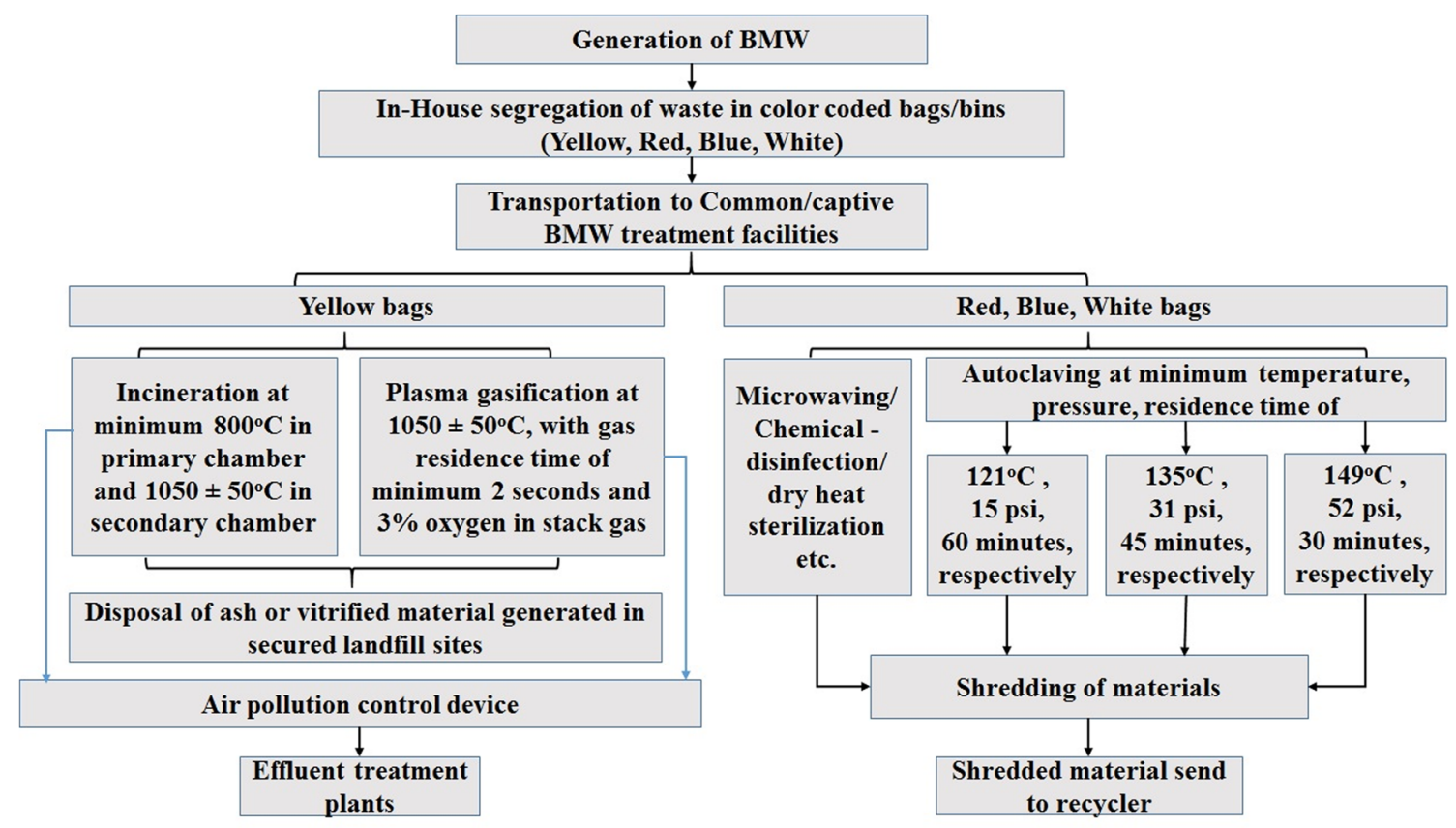

Fig. 5 Regulatory framework for BMW

have certain limitations. In recent years, non-incineration technologies such as high-temperature steam and microwave-based technologies are becoming popular in some countries (Chen et al. 2013a; Khoo et al. 2021). More details could be found elsewhere (Zimmermann 2017).

The yellow category (Y-BMW) is collected in nonchlorinated bags and is incinerated in CBMWTFs. All the CBMWTFs have double chamber modular incineration system, with incineration capacity ranging from 50 to $200 \mathrm{~kg} / \mathrm{h}$. The incinerators are designed for the combustion efficiency of $>99 \%$. Wastes are fed into the primary chamber in batches of about one-fifth the capacity of the chamber. The primary and secondary chamber temperatures are maintained at a minimum of $800^{\circ} \mathrm{C}$ and $1050 \pm 50^{\circ} \mathrm{C}$, respectively. The air supply is regulated between 30 and $80 \%$ and 120 and $170 \%$ of the stoichiometric volume in the primary and secondary chambers, respectively (CPCB 2016b, c). This controlled air supply in the primary chamber and excess air in the secondary chamber minimize particulate matter generation and efficient destruction of organic pollutants such as polycyclic aromatic hydrocarbons (PAHs), dioxins, and furans. According to BMW regulations, flue gases' residence time (RT) in the secondary chamber should be at least $2 \mathrm{~s}$. However, most of the CBMWTFs constructed before 2016 have been designed for 1-s RT. All incinerators are equipped with wet/packed bed scrubbers to remove particulate matter and acidic vapors. Few incinerators that came up after 2016 are equipped with activated carbon filters to remove dioxins and furans. The flue gases are let out via a stack of $30 \mathrm{~m}$ in height. Ash generated in incinerators is disposed of in hazardous waste landfills (CPCB 2016a, b, c).

\section{Status of BMW treatment and disposal facilities in India}

There are 322,425 HCFs in India, out of which 153,885 are granted authorization under the BMW rules 2016, and more than 29,000 HCFs violated the BMW rules in 2019 (CPCB 2019b). BMW generated in India is managed by CBMWTFs and captive BMW treatment systems (C-BMWTS). CBMWTFs are common infrastructural facilities where BMW from multiple HCFs is treated and disposed of in economical and viable ways. There are 202 CBMWTFs in India, and another 35 are under construction stage. C-BMWTS treat and dispose of the BMW generated from individual HCF. The BMW Management Rules 2016 restrict the installation of CBMWTS if CBMWTF is available within $75 \mathrm{~km}$ of distance. CBMWTFs avoid the scattering of treatment systems in the area/city. In addition, these facilities are much easier and economical to operate and monitor compared to scattered CBMWTS. Still, more than 18,000 HCFs in India have CBMWTS. Only $136 \mathrm{HCFs}$ have captive incinerators, which means the rest of HCFs only use deep burial methods. India generates 619 t/day of BMW, out of which CBMWTFs treat about $489 \mathrm{t} /$ day, $55 \mathrm{t} /$ day by C-BMWTS, and the remaining $74 \mathrm{t} /$ day is disposed of in remote areas by deep burial method (CPCB 2016a, 2019b). Deep burial of waste in remote areas is adopted due to distance constraints between the HCFs and CBMWTFs.

The total capacity of all the CBMWTFs is about 840 t/day (Shammi et al. 2021). The incinerators are very difficult to operate if they are fed with more than $70 \%$ of their capacity. India generates $619 \mathrm{t} /$ day of BMW, which is less than 840 
t/day, still many states have exceeded their utilization capacity. In states, namely Assam, Kerala, Tamil Nadu, Jammu Kashmir, Meghalaya, Odisha, and Tripura, the capacity utilization of existing facilities has already exceeded $70 \%$. Therefore, these states should conduct gap analyses in each coverage area to determine the need for additional facilities. Some states/UTs, viz. Sikkim, Nagaland, Mizoram, Goa, Arunachal Pradesh, Andaman Nicobar, and Dadar Nagar Haveli, do not have any CBMWTFs; hence, these states/ UTs should set up new facilities of suitable capacities (CPCB 2019b).

\section{Increase in BMW during the COVID-19 pandemic}

In India, the composition and distribution of BMW are highly variable which depends on various factors. These include the efficiency of segregation at source, knowledge of healthcare workers, accessibility, and availability of CBMWFTs. Studies also indicate that the generation and type of BMW also depend on HCFs, recyclable and reusable items, the number of patients handled daily, etc. (Devi et al. 2019; Thind et al. 2021). Due to the COVID-19 outbreak, the sharp increase of PPEs, other medical gears, etc., have drastically affected the waste management system. More than $340 \mathrm{M}$ passengers were handled by airports in India during 2020, which includes $274 \mathrm{M}$ domestic and $66 \mathrm{M}$ international passengers. Due to COVID-19, all the airlines started providing PPE kits to the passengers. It means, approximately $340 \mathrm{M}$ aprons, face masks, face shields, gloves, sanitizer sachets were used by air travellers in India (https://www.statista.com/statistics/ 588028/passengers-boarded-by-type-by-indian-air-carriers/). India requires about $2.5 \mathrm{M}$ of PPE kits every day to combat the spread of COVID-19 virus (Parashar and Hait 2021). The material composition of PPEs include about $20-25 \%$ by weight of plastic, especially PP (Singh et al. 2020a). This vast quantity of plastic is destined for landfilling or incineration, thus causes environmental pollution.

Figures 6, 7, and 8 show the COVID-19-based BMW (CBMW) generation in Indian states/UTs during September 2020 and May 2021. The major contributing states/UTs to C-BMW during the 1st wave (September 2020) were Gujrat, Tamil Nadu, Maharashtra, Uttar Pradesh, Kerala, West Bengal, Delhi, Madhya Pradesh, Haryana, and Punjab, which contributed about $80 \%$ of the total C-BMW. The average CBMW generation was 183 t/day during September 2020 . During the 2nd wave (May 2021), the average C-BMW generation was $203 \mathrm{t} /$ day. The top contributing states/UTs were Kerala, Gujrat, Maharashtra, Delhi, Karnataka, Uttar Pradesh, Tamil Nadu, Haryana, Andhra Pradesh, and Madhya Pradesh. Lakshadweep generated the lowest quantity of C-BMW during both waves, $10 \mathrm{~kg} /$ day (CPCB 2020a).

\section{Number of active cases and C-BMW generation}

Figure 9 shows the positive correlation between the number of COVID-19 active cases and the average C-BMW generation. Also, it is observed that as the number of COVID-19 active cases increases, the C-BMW also increases and vice versa. During the peak of the 1st wave, the C-BMW generation was $183 \mathrm{t} /$ day, and during the peak of the 2 nd wave, the CBMW generation was around $203 \mathrm{t} /$ day. The number of active cases during the peak of the 2nd wave was 3.7 times that of the 1 st wave. Still, the C-BMW generation rate differed only by about $20 \mathrm{t} /$ day. The knowledge about the COVID-19 virus and its dissemination, the decrease in the fear, and timely policy intervention by $\mathrm{CPCB}$ on segregation and management helped reduce waste generated during the second wave. It is to be noted that during the 2 nd wave, only patients with severe symptoms with other comorbidities were advised for hospitalization, and the rest were advised to remain in home isolation/ quarantine. C-BMW generated at home do not have access to CBMWTFs; hence, they were generally disposed of with municipal solid waste (MSW). This practice has increased the MSW generation drastically in India and in other developing countries as well (Kulkarni and Anantharama 2020; Vanapalli et al. 2021; Das et al. 2021a). Even developed countries with a well-established MSW management system reported a surge in MSW generation due to the disposal of PPEs in MSW (Das et al. 2021b).

\section{BMW and PW generation from vaccination centers}

COVID-19 pandemic has already added a massive amount of PW and BMW and will continue to generate PW and BMW until it ceases. Many organizations are working on medicines and vaccines for the novel virus to stop this pandemic. Several pharmaceutical companies have successfully launched their vaccines in the market. Bharat Biotech developed India's first indigenous vaccine, the Covaxin. The Serum Institute of India (SII) introduced the Covishield vaccine in collaboration with Oxford-Astra Zeneca. The vaccination program in India was launched on 16th January 2021. Although vaccination drive is necessary for the current situation, it also adds a vast amount of BMW and PW such as syringes, gloves, and vaccine containers. India has become the world's fastest country to administer $140 \mathrm{M}$ vaccine doses in just 100 days (https://www. covid19india.org/). The current population of India is more than 1.39 billion (worldometer 2021). It is estimated that the vaccination of the entire country will generate about 2.78 billion syringes, gloves, and vaccine containers. Therefore, it is very essential to properly collect, segregate, and dispose of all the waste generated during vaccination. 
Fig. 6 The average C-BMW generation by different states/UTs in India $(\mathrm{kg} /$ day)

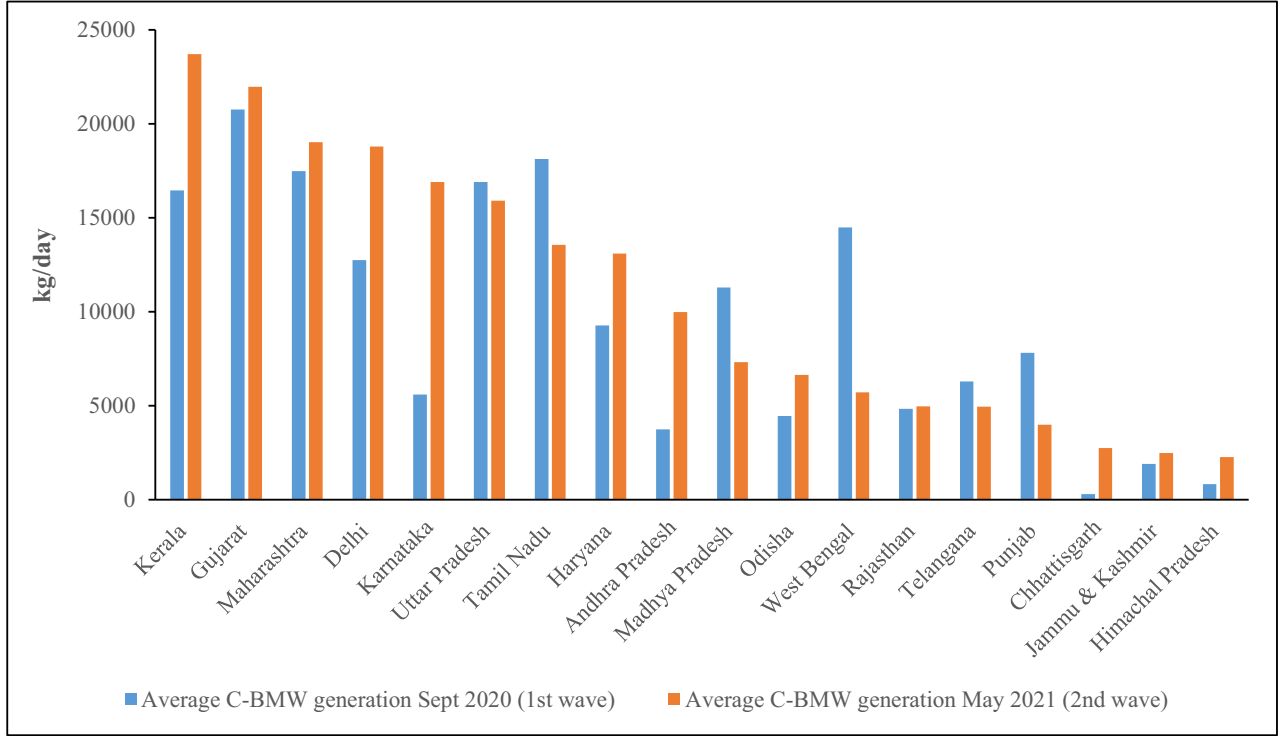

Waste management facilities commonly cater to steady-state flow of waste with moderate fluctuations in the composition and quantity (Parashar and Hait 2021). The sudden change in waste quantity and composition caused by the pandemic affected the regular operations of present treatment facilities. Due to the widespread use of PPEs, medical gears, and SUPs, the world is on the verge of devising a worldwide waste pandemic unless it is successfully monitored and addressed. Inadequate PW management, littering poses the threat of viral spread and pollutes the terrestrial and aquatic environments (Sarkodie and Owusu 2020). Improper handling of wastes that contaminate the environment could also be caused by the dearth and discrepancies in current waste management processes, such as limited personnel and capacity constraints.

\section{Inadequate infrastructure facilities for BMW treatment}

In the present scenario, onsite waste segregation is minimal due to the sudden rise in BMW generation, fewer employees available, and the fear of infection in HCFs. This poses a high probability of infection risk to waste management agencies responsible for the collection, segregation, treatment, and disposal. India's current BMW generation has reached more than 800 t/day (Chand et al. 2021). Most of the CBMWTFs have small incinerators, i.e., $50-200 \mathrm{~kg} / \mathrm{h}$, and some states are not in a position to handle BMW even before the pandemic. Inequalities in the geographical distribution of CBMWTFs and the higher number of COVID-19 cases reported in some
Fig. 7 The average C-BMW generation by different states/UTs in India ( $\mathrm{kg} /$ day)

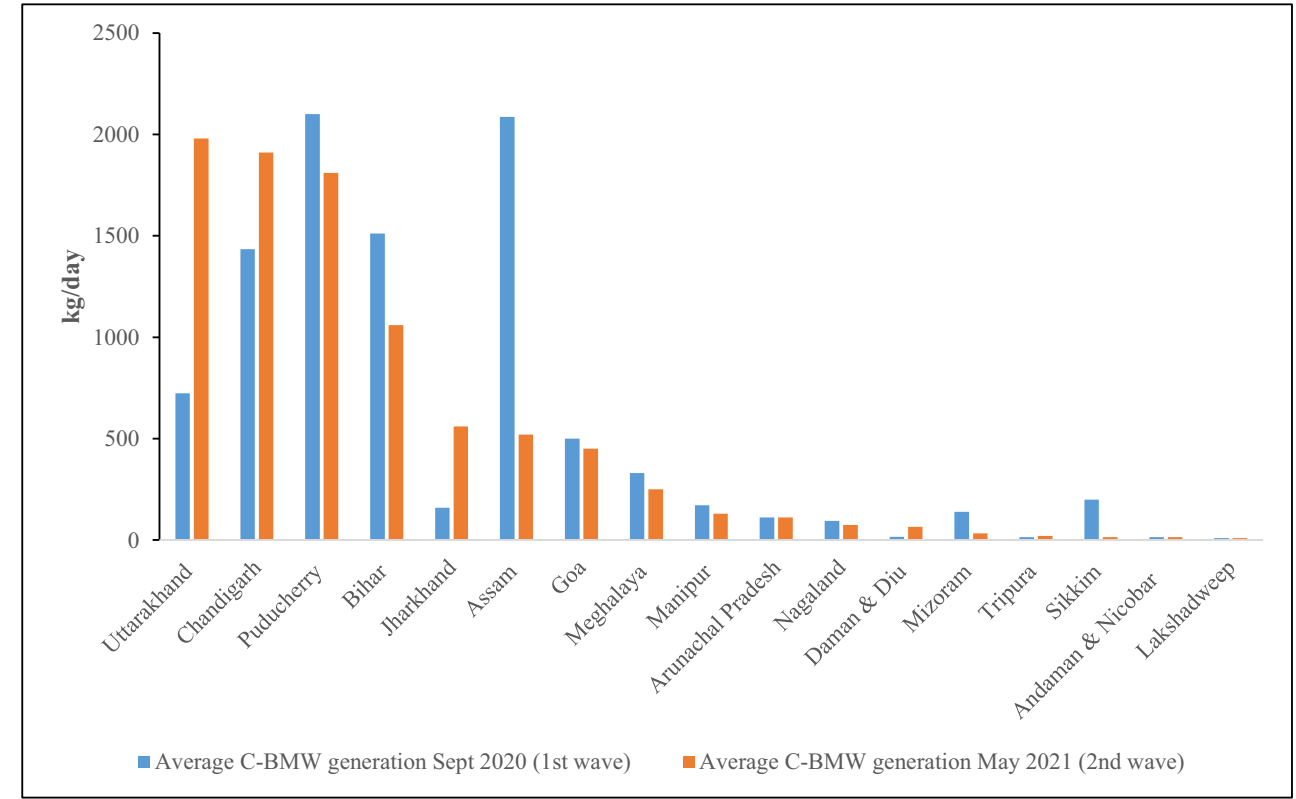


Fig. 8 Top ten states/UTs generating C-BMW during May 2021

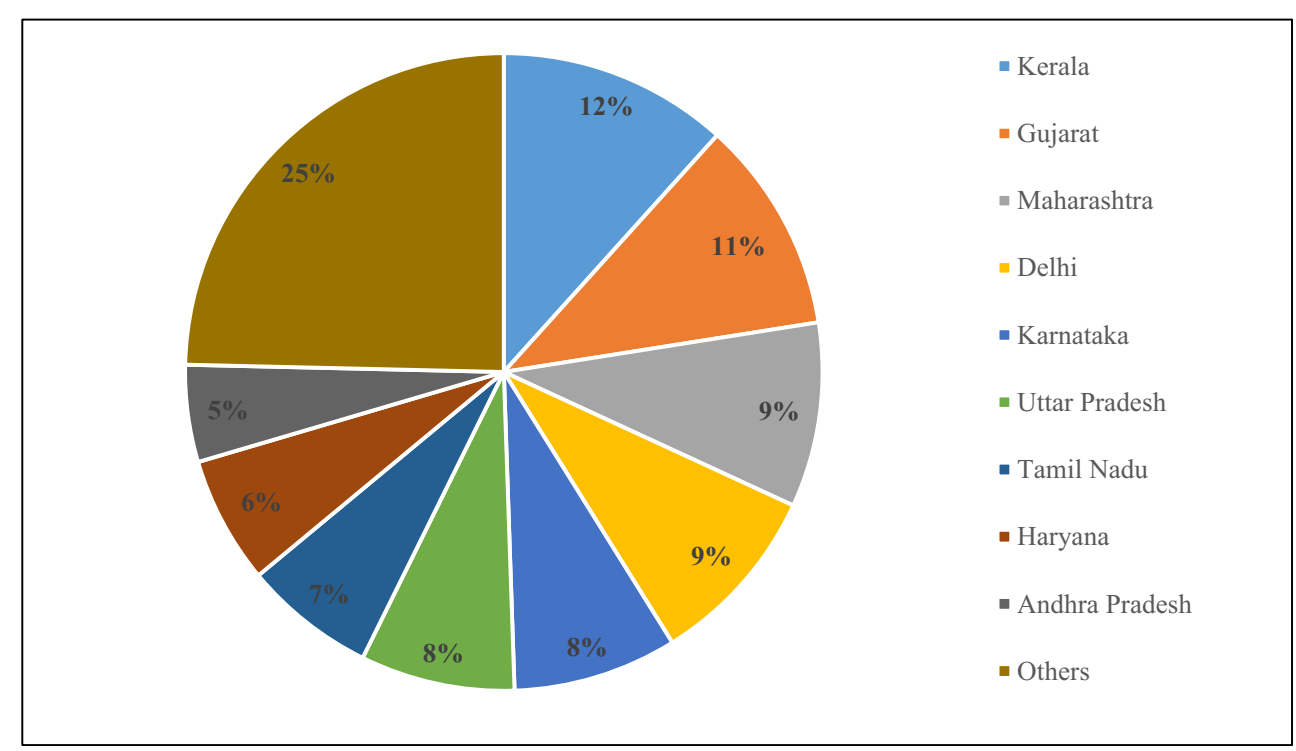

states further aggravated the situation. Considering the logistics and employees involved in the BMW management, it is observed that incinerators working $>70 \%$ of their capacity are likely to face difficulties in the operation (CPCB 2020a, b). The states such as Andhra Pradesh, Chhattisgarh, Haryana, Madhya Pradesh, Maharashtra, and Telangana have the adequate capacity of CBMWTFs. The incinerators in states viz. Bihar, Jammu Kashmir, Karnataka, Kerala, Odisha, Rajasthan, Tamil Nadu, Uttar Pradesh have exceeded the $70 \%$ utilization capacity, thus need to identify alternate incinerators/disposal options (Table 1). These circumstances would certainly lead to compromised or inefficient treatment conditions. (CPCB 2019b).

\section{Policy intervention for C-BMW management}

The COVID-19 disease outbreak has led to an exceptionally high volume of BMW due to PPEs and other dedicated patient care items used by health care professionals and patients. In addition, the use of face masks, hand sanitizers, and surface disinfectants has become mandatory for the general public to
Fig. 9 The relationship between the number of active cases in India in the mid of the month and C-BMW generation

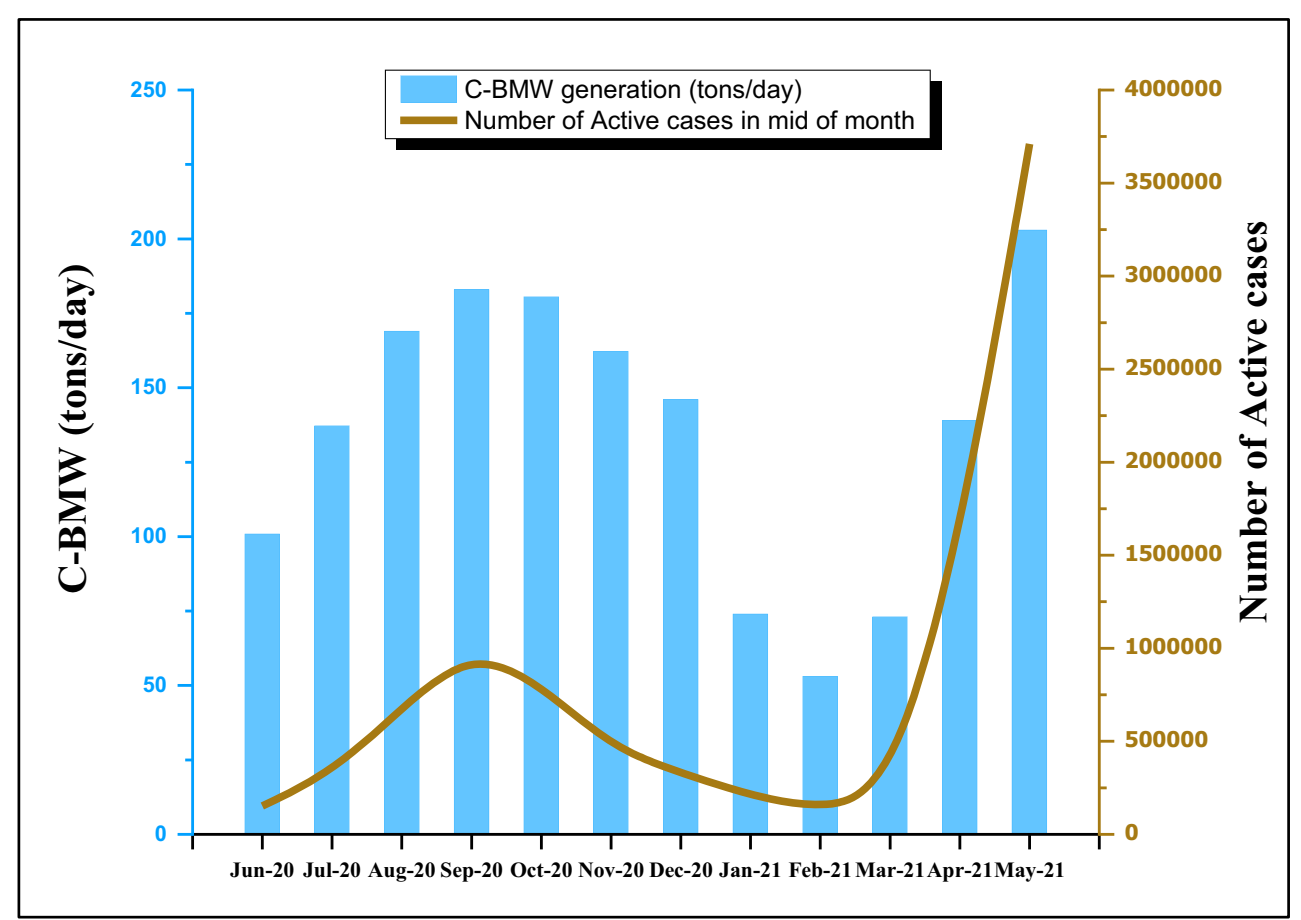


Table 1 Inequalities in the geographical distribution and capacity utilization of CBMWTFs in some states of India

\begin{tabular}{|c|c|c|c|c|c|c|}
\hline Name of state & $\begin{array}{l}\text { Number of CBMWTF } \\
\text { engaged }\end{array}$ & $\begin{array}{l}\text { Authorized capacity } \\
\text { (t/day) }\end{array}$ & $\begin{array}{l}\text { BMW } \\
\text { (t/day)* }\end{array}$ & $\begin{array}{l}\text { C-BMW } \\
\text { (t/day) }^{* *}\end{array}$ & $\begin{array}{l}\text { Total (BMW } \\
+ \text { C-BMW), } \\
\text { t/day }\end{array}$ & $\begin{array}{l}\text { Capacity utilization } \\
(\%)\end{array}$ \\
\hline Andhra Pradesh & 12 & 44.4 & 15.1 & 9.99 & 25.09 & 56.5 \\
\hline Assam & 1 & 7.2 & 8.8 & 0.52 & 9.32 & 129.4 \\
\hline Bihar & 4 & 45.3 & 34.8 & 1.06 & 35.86 & 79.2 \\
\hline Chandigarh & 1 & 6.5 & 3.9 & 1.91 & 5.81 & 89.4 \\
\hline Chhattisgarh & 4 & 22.8 & 7.07 & 2.76 & 9.83 & 43.1 \\
\hline Delhi & 2 & 62.8 & 28.8 & 18.79 & 47.59 & 75.8 \\
\hline Gujarat & 20 & 103.9 & 36.4 & 21.98 & 58.38 & 56.2 \\
\hline Haryana & 11 & 83.4 & 14.8 & 13.11 & 27.91 & 33.5 \\
\hline $\begin{array}{l}\text { Himachal } \\
\text { Pradesh }\end{array}$ & 2 & 9.2 & 3.4 & 2.27 & 5.67 & 61.6 \\
\hline $\begin{array}{c}\text { Jammu and } \\
\text { Kashmir }\end{array}$ & 3 & 9.8 & 5.9 & 2.49 & 8.39 & 85.6 \\
\hline Jharkhand & 4 & 13.1 & 7.6 & 0.56 & 8.16 & 62.3 \\
\hline Karnataka & 27 & 108.4 & 77.5 & 16.91 & 94.41 & 87.1 \\
\hline Kerala & 1 & 48 & 42.9 & 23.71 & 66.61 & 138.8 \\
\hline Madhya Pradesh & 12 & 46.5 & 17.8 & 7.32 & 25.12 & 54.0 \\
\hline Maharashtra & 31 & 130.9 & 62.3 & 19.02 & 81.32 & 62.1 \\
\hline Manipur & 1 & 2.6 & 1 & 0.13 & 1.13 & 43.5 \\
\hline Odisha & 5 & 14.9 & 18 & 6.65 & 24.65 & 165.4 \\
\hline Punjab & 5 & 29.1 & 16.05 & 4 & 20.05 & 68.9 \\
\hline Rajasthan & 8 & 35.3 & 20.7 & 4.98 & 25.68 & 72.7 \\
\hline Tamil Nadu & 8 & 72.9 & 58.3 & 13.57 & 71.87 & 98.6 \\
\hline Telangana & 11 & 118.7 & 20.5 & 4.96 & 25.46 & 21.4 \\
\hline Uttarakhand & 2 & 7.5 & 3.8 & 1.98 & 5.78 & 77.1 \\
\hline Uttar Pradesh & 18 & 91.3 & 52.5 & 15.91 & 68.41 & 74.9 \\
\hline West Bengal & 6 & 79.9 & 41.6 & 5.72 & 47.32 & 59.2 \\
\hline
\end{tabular}

* Denotes the BMW generation of 2019 and ${ }^{* *}$ denotes the C-BMW generation for May 2021

prevent the highly contagious virus. Furthermore, numerous latest materials launched in the market for detection, testing, diagnostic, and treatment of patients also contributed towards BMW. Advisories issued by the World Health Organization (WHO 2020) helped countries to make appropriate policy decisions regarding the safe disposal of HCW. The Basel Convention on the transboundary movement of hazardous wastes and their disposal has issued guidelines immediately after the onset of the pandemic, i.e., 20th March 2020. The Basel Convention urged all countries to recognize BMW management as an essential public health service to minimize possible secondary impacts upon health and the environment. In India, the CPCB is responsible for the implementation of BMW (2016) rules. CPCB issued guidelines to treat BMW management as "essential services" and ensured the uninterrupted movement of vehicles and people involved in BMW management. Further policy interventions include an adequate supply of yellow, red, white, and blue bags/containers to all the hospitals and quarantine facilities for onsite segregation and collection of waste. For final disposal, BMW should be transferred to CBMWTFs. If CBMWTFs are not available, the waste produced can also be taken to the nearest authorized hospital for incineration at C-BMWTS. The guidelines mandated the use of PPEs by all the people dealing with BMW in isolation wards. Figure 10 depicts the BMW category, waste types, bags/containers used for storage, treatment, and disposal (CPCB 2016a, b, c).

CPCB issued the first policy intervention on 18th March 2020 for the safe handling and disposal of C-BMW (CPCB 2020c). These were in addition to the existing BMW and Solid Waste Management (SWM) Rules, 2016 (CPCB 2016c, d). These guidelines suggest using double-layered bags for collecting waste from quarantine/isolation centers to assure sufficient strength and safeguard from any leakages. Usage of dedicated bins labeled as "COVID-19 waste" is suggested. The collected waste should be transferred to CBMWTFs or C-BMWTS for safe disposal. All the personnel handling C-BMW should be provided with PPE kits. The 
Fig. 10 BMW categories, type of bags or containers used, and their disposal

\section{Type of Bags/Box}

Non-chlorinated Plastic or semi

plastic bags

(Autoclavable)

\section{Type of waste}

Masks - (N95, Triple layer masks

etc.)

- Shoe-cover

- Head cover/cap

- Tissues, toiletries

- Disposable linen gown

- gloves and tissues or swabs syringes, medicines etc. contaminated with body fluids/ blood of COVID-19 patients

- Donned of PPE

- PPE with spill

- Diapers used by COVID-19 natient

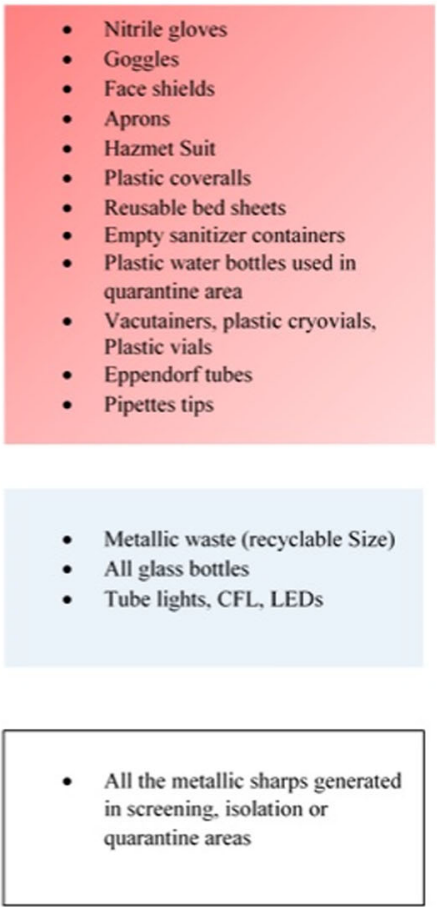

Treatment/

Disposal

- Plasma pyrolysis in CBMWTFs or C-BMWTS

- Incineration

- Deep burials

if no other option

\section{Non-chlorinated}

Plastic bags

(Autoclavable)

Cardboard

containers

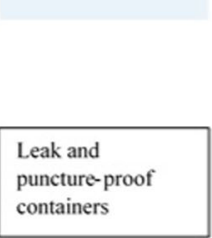

-

Sterilizing the waste by autoclaving. hydroplaning or radiationbased

- Treated/Sterili zed waste should be sent for the recycling sterilization

- Sent for the recycling

Wet or dry heat sterilization

- Sterilized waste is shredded or mutilated/ encapsulated and sent for landfill bins, containers, and trolleys used for C-BMW transportation or storage should be thoroughly disinfected with $1 \% \mathrm{NaOCl}$ solution (CPCB 2020c). During the implementation of the first guidelines, the reported number of cases was about 200 in India (worldometer 2021), and C-BMW's generation was far less compared to the current scenario. Thus, it was comparatively easy to dispose of the total generated C-BMW in CBMWTFs. The increase in knowledge about the health and environmental impacts, the severity of the virus, and an increase in COVID-19 cases in India, vis-à-vis the global best practices, led to CPCB issue 2nd, 3rd, and 4th amendments in just 5-6 months (Kulkarni and Anantharama 2020; Sangkham 2020).

The second revision of guidelines was issued on 19th April 2020. The reported COVID-19 cases were more than 16,000 on 18th April 2020 (worldometer 2021). Diapers used by
COVID-19 patients who cannot use toilets are to be treated as Y-BMW or incinerable waste. Used masks, caps, head covers, plastic/semi-plastic coverall, shoe cover, disposable linen gowns, etc., are to be stored in yellow containers. PPEs involving face shield, splash-proof aprons, goggles, hazmat suit, pre-treated viral transport media, vacutainers, plastic vials, cryovials, pipette tips, etc., should be stored in red bags. Gloves and masks generated from households are to be wrapped in paper bags and stored for at least $72 \mathrm{~h}$ before disposal. This storage period is aimed to deactivate the virus residing on certain surfaces (Kampf et al. 2020). It is also suggested to cut the masks, gloves before disposal to avoid reuse. These guidelines also permit the disposal of Y-BMW in remote areas by deep burials in the absence of CBMWTFs or CBMWTS (CPCB 2020d). 
The 3 rd revised guidelines were issued on 10th June 2020 by CPCB. The total number of COVID-19 cases increased to $0.25 \mathrm{M}$ in India on 9th June 2020 (worldometer 2021). In this amendment, the guidelines on the segregation of BMW and general solid waste (GSW) were given importance due to the surge in GSW generation. In addition, this amendment also addresses the safety of workers associated with CBMWTFs in handling BMW and other wastes generated from HCFs treating COVID-19 patients, homecare, and quarantine centers. This amendment suggested the use of color-coded containers with foot-driven lids. GSW such as wrappers of syringes, medicines, empty juice or water bottles, discarded papers or carton boxes, and fruit peel-offs, which were not contaminated by COVID-19 patient's body fluids/blood, should be collected and disposed of as per SWM rules 2016 (CPCB 2016d). Non-disposable products, which could be cleaned, handled, and disinfected, must be reused to decrease waste generation. Items such as disposable plates, glass, food leftover, used tissues, toiletries, and masks, used by COVID-19 patients, shall be treated as Y-BMW. Due to the large quantity of Y-BMW generation beyond the capacities of CBMWTFs and C-BMWTS, these guidelines permit BMW disposal by hazardous waste (HW) incinerators. In such scenario, arrangements for separate handling and feeding should be ensured. Waste handlers should be aware of basic knowledge on hand hygiene, social distancing, PPEs, waste segregation, and disposal (CPCB 2020e; WHO 2020).

The 4th revision of guidelines was issued on 17 th July 2020 by CPCB. The total number of COVID-19 cases reached more than $1 \mathrm{M}$ in India on 16th July 2020 (Worldometer 2021). This amendment issued revised guidelines for segregation of GSW and BMW from isolation, quarantine centers, homecare, and HCFs. Yellow-colored bins should not be used for the collection of GSW. Segregation of BMW and GSW should be done at the waste generation site itself. The discarded PPE used by the general public should be stored in separate containers for at least $72 \mathrm{~h}$; after that, it can be shredded and disposed of as dry GSW. PPEs doffed by health personnel accompanying the dead body of COVID-19 patients to graveyard/crematories should be treated as BMW. Used gloves and masks from graveyards/ crematorium visitors should be collected in separate containers/bins and stored at least $72 \mathrm{~h}$ before disposal as GSW (CPCB 2020f).

Another remarkable policy intervention to track the CBMW management has been the launch of the software application, "COVID19BMW," for monitoring the generation, collection, and disposal of C-BMW from various HCFs, homecare centers, isolation/quarantine areas, sample collection centers, testing areas, etc. HCFs and CBMWTF operators are mandated to use this App to report the quantity of waste generated and treated. This App enables knowledge sharing among different stakeholders involved.
Although CPCB issued policy guidelines based on the experience and global best practices, BMW management during the COVID-19 pandemic appears inadequate due to the weak infrastructural and regulatory issues. This is manifested by the National Green Tribunal's (NGT) intervention. This judicial body deals with environmental problems in India on the matter related to the disposal of C-BMW (CPCB 2020b). The NGT, in its order, pointed out regulatory and implementation gaps exist in the (a) deep burial methods, (b) absence of BMW collection, storage, and disposal mechanism in villages and rural areas, (c) disposal with general waste, and (d) lack of awareness among stakeholders. India's rural population is about $65 \%$; hence, the impact of improper methods of BMW disposal may have severe environmental and public health consequences. This is mainly due to the absence of adequate infrastructural requirements for the sound management of BMW and general waste in India and most other developing countries (Nzediegwu and Chang 2020). Poor MSW management and improper disposal of used PPEs may result in the spread of the COVID-19 virus, given its persistence up to 9 days (Kampf et al. 2020).

\section{Environmental and health consequences of inefficient incineration of BMW}

Incineration is the principal mode of disposal of C-BMW at CBMWTFs or C-BMWTS. The quantity of Y-BMW ranges from 34 to $70 \%$ of the total BMW, with an average of $50.4 \%$ (Thind et al. 2021). Incineration involves a remarkable reduction in waste volume and weight. This process is adopted for waste that is neither reusable nor recyclable due to its highly infectious nature. Used PPEs and SUP products in C-BMW are likely to generate more toxic organic compounds such as dioxins, furans, PAHs, and polychlorinated biphenyls (PCBs), during incineration. PPEs generally contain $25 \%$ of polymers such as PP and PE, and studies have shown that incineration of plastics produces more unintentional persistent organic pollutants such as PCBs, PAHs, dioxins, and furans (Shibamoto et al. 2007; Chen et al. 2013b; Singh et al. 2020a, b). In addition, microplastics, one of the emerging environmental pollutants, are detected in incineration ashes during recent times (Shen et al. 2021).

During the first and second wave of COVID, the surge in the generation of BMW has been experienced by various CBMWTFs. Even before the onset of COVID-19, some states have already exceeded the $70 \%$ utilization of the authorized capacity (CPCB 2019b). Table 1 indicates the exceedance of treatment capacity of several states, but still, these states are compelled to treat the BMW in CBMWTFs available within the states. Feeding more waste, i.e., above one-fifth of the chamber capacity into the primary chamber, may not result in the recommended combustion efficiency of $99 \%$, leading to 
incomplete combustion. To combat this, CPCB granted authorization to use hazardous waste incinerators (HWI) for BMW incineration. However, HWI are very few in India (only 12); most are located in industrialized states such as Gujarat, Maharashtra, Ghaziabad (Delhi), and Tamil Nadu, and may not be much helpful in reducing the burden on the CBMWTFs. Details of BMW incinerated in HWI are not available.

Due to the lack of engineered landfills in India, the PPEs disposed of with MSW are predominantly destined to informal dumping sites. PPEs are mainly made of non-woven spunbond meltbond spunbond (SMS) fabric, which can degrade into microplastics. Similarly, SUPs are lightweight, easily carried away by wind and scattered over land and water bodies, and may pose hazards to terrestrial and aquatic organisms. SUPs may further increase the visual plastic pollution as well as microplastic levels in land and water resources in the near future. The deep burial method adopted by HCFs having captive treatment facilities may also likely to increase soil microplastic contamination. However, it remains to be seen, as data on the disposal of BMW by deep burial methods are currently not available.

\section{Possible management strategies and solutions}

Inadequate infrastructure for waste treatment and disposal is one of the major issues in developing countries, including India. During pandemic times, it is always human health and safety which get priority over other issues. However, if adequate attention is not paid, the pandemic waste would pose severe environmental health consequences in the future. Though India has responded well with various policy interventions based on experience gained and quick in adopting the policy guidelines of $\mathrm{WHO}$, it should improve the infrastructure for the management of MSW, BMW, and PW for the successful implementation of these interventions. It might take some time to see how accurately the added waste will impact the environment. Moreover, the BMW and plastic produced during the pandemic could be used as a benchmark for emergency and protracted waste management practices, enabling us to create a safer and healthier tomorrow. Robust, viable approaches and strategies are needed to deal with waste generated during the global pandemic. Amelioration in technology along with sustainability is required to deal with the pandemic. Some plans or initiatives could need immediate attention and action, whereas others may require considerable attention in the long run (Vanapalli et al. 2021). The emergency preparedness and safety systems are obligatory for all countries to tackle the enormous rise of BMW and SUPs during the pandemic.
- The SUPs and BMW should be disposed of safely to barricade virus spread and curtail the adverse effects on the environment. Color-coded bins should be used to ensure effective collection and disposal (Datta et al. 2018; Das et al. 2021b). The BMW management guidelines (CPCB 2016a, 2020f) should be referred to and adopted to segregate, collect, store, transport, and dispose of the waste generated. Instead of any interim actions and transitional policies, a universal strategic plan has to be drawn up. Local authorities may provide specific color-coded bags to the households (home quarantine centers) to discard the PPEs. This will improve onsite segregation of BMW. Furthermore, specific color-coded bins may be placed in community centers/public places.

- Investment in health infrastructure and hiring of skilled health professionals are required to improve the treatment capacity (Shammi et al. 2020; Deepak et al. 2021). The successive usage of mobile equipment and expanding everyday treatment capabilities of stationary stations are appropriate responses to tackle the COVID-19 pandemic. Several mobile incinerators of $>50 \mathrm{t} /$ day capacity were installed in Wuhan city to tackle the C-BMW. The mobile facilities are helpful in pandemic situations but its sustainability is to be ensured (Shammi et al. 2021). This is true for countries such as India, as the generation of C-BMW is highly variable. For instance, during May 2021, the number of active cases in northern states of India was comparatively less than that in southern states and so the C-BMW generation. One possible solution is shifting mobile incinerators to other states in such situations.

- There is an urgency to increase the treatment capacity of incinerators in CBMWTFs and C-BMWTS. Currently, most of the incinerators in India are of the modular type, with capacity ranging from 50 to $200 \mathrm{~kg} / \mathrm{h}$. Due to the massive C-BMW generation, there is a need to switch to higher capacity modular, rotary, and fluidized bed incinerators. But at the same time, one should look at the scenario and use of these higher capacity incinerators after the COVID-19 pandemic. Thus, at the designing stage, focus should be on designing appropriate capacity incinerators depending on the population and number of HCFs. The current limit of 75-km radius for BMW collection could be increased for large capacity incinerators. All incinerators should be equipped with suitable air-pollution control and monitoring devices. Activated carbon filters can be utilized to remove dioxins, furans, and other unintentional POPs.

- Given the current compromised SUP and PPEs disposal method, it is necessary to increase monitoring (aquatic, terrestrial, and aerial surveys) of PW under the postCOVID-19 situation. Studies should address the environmental fate, behavior, degradability, and effects of used PPEs, plastic additives, the potential for pathogens 
transfer, and sorption/desorption capacities of POPs like pollutants.

- Considering the public health and safety during the pandemic, there is a need to develop more advanced and automated systems (based on the Internet of Things) for BMW management with the minimum number of workers involved (Das et al. 2021b). Incorporating artificial intelligence in existing and emerging facilities for segregation, processing, etc., will decrease the burden on manual facilities and help waste management systems operate more efficiently.

- HCFs must consider various decontamination approaches for recycling and reuse of PPEs. Different disinfection approaches such as hydrogen peroxide vapors, washing, UV germicidal lamps, moist heat, gamma irradiation, 75\% alcohol solution, ethylene oxide, etc., are used in other countries (Ilyas et al. 2020; Kampf et al. 2020; Rowan and Laffey 2020; Khoo et al. 2021; Liu et al. 2021; Mohanan et al. 2021). Decontamination techniques would limit the plastic supply and minimize PW generation while facilitating sustainability practices. Reusable and recyclable products are to be encouraged (Singh et al. 2020b). Instead of plastic-based, widely available masks, the use of fabric masks should be encouraged (Silva et al. 2020). If people start wearing reusable masks rather than singleuse masks, it can diminish the waste generation and risk of contamination due to disposal. Reusable masks will also help in securing the supply of single-use masks for health workers.

- The emphasis should be on developing innovative and sustainable ways for recycling mixed and other complex plastic products. High recyclability rates and high-quality goods could be achieved by incorporating artificial intelligence into the segregating and processing stages. It is essential to recognize and reward well-operating recycling plants and highlight them in the media to encourage others. Complex and economically unrecyclable materials, such as multi-layer packaging, should be restricted. Policies to reduce multi-layer plastics and promote homogeneous plastic packaging should be formulated as a longterm plan to enhance PW recycling efficiency.

- Modern methods such as hydrothermal carbonization, based on high temperature, and autoclaving pressure techniques can be used for BMW carbonization (Shen et al. 2017; Sharma et al. 2020).

- Co-processing of BMW mainly in cement kilns is an excellent solution to save our planet from the waste pandemic. In this process, the wastes get destroyed at around $1450^{\circ} \mathrm{C}$ temperature, longer residence time, and leave no residue. Apart from utilizing the energy content of waste, its inorganic portion gets fixed with the clinker and becomes part of cement. Furthermore, the alkaline environment within the kiln helps in neutralizing the acidic gases generated during the co-processing. This method also decreases the demand for non-renewable energy resources such as limestone and coal (CPCB 2017a, b).

- The development of eco-friendly PPE kits should be promoted. The production industry must concentrate on using compostable or biodegradable plastics such as bio-plastics manufactured by biomass usage. Appropriate facilities must be established for managing such bio-plastics. To protect ourselves from the plastic pandemic, we should also opt for refillable soap dispensers and hand sanitizers. The production of such greener goods should be incentivized and rewarded.

- Companies and industries should be encouraged to finance the startups working in PW and BMW management. The resources and funds issued by the industries should be considered as a portion of extended producer responsibility.

- Currently, only construction and demolition wastes (generated mainly during the disasters like earthquakes, hurricanes, and tsunamis) are included in disaster waste. CBMW and other wastes generated in the future pandemics can also be included in disaster waste; separate rules and regulations should be formed to deal with such waste in the near future.

- Waste management ought to be included in the disaster management plan. Additional directives and response measures should be formulated to respond and manage the waste produced during future pandemics. It is necessary to ensure that the people engaged are well aware of handling BMW, which could be accomplished by establishing a common knowledge-sharing forum.

- Awareness programs, media campaigns must be launched to make the public more aware of the environmental effects of haphazard dumping and poor governance of PW and BMW. The public should also take responsibility for the adequate disposal of PW. Furthermore, to raise awareness among future generations, the environmental impacts of BMW and PW should be introduced in the school curriculum. Efforts to address fear-driven perceptions about the hygiene of recycled and reused materials should also be taken into consideration.

\section{Limitations of the study}

The primary objective of this study is to review the regulatory framework and the institutional capacity to manage the unpredictable volume of BMW generation during the COVID-19 pandemic. Data on BMW generation was obtained from published reports of regulatory agencies. Monthly data on BMW generation is available only statewise; hence, it may not be possible to identify "critical areas" where BMW management 
requires improvement. Sub-catogories of BMW generated and disposed, i.e., yellow, red, blue, and white, are also not available. Considerable quantity of PPE is disposed of with MSW, especially by non-infected people. Also, underreporting of data is an issue in areas where the regulatory mechanism is weak. Despite these limitations, the conclusions and perspectives of this study represent the regional levels and must be helpful to researchers and policymakers.

Acknowledgements The authors would like to thank Director, CSIRNEERI, for granting permission to publish the paper. The authors thank the anonymous reviewers for their critical comments which helped to improve the manuscript.

Author contribution Designing, conceptualization, data collection, and data analysis were performed by AD, ANV, and ARK. All authors read and approved the final version of the manuscript.

Data availability All the data referred in this paper are available in the public domain.

\section{Declarations}

Ethics approval and consent to participate Not applicable.

Consent for publication Not applicable.

Competing interests The authors declare no competing interests.

\section{References}

Benson NU, Bassey DE, Palanisami T (2021) COVID pollution: impact of COVID-19 pandemic on global plastic waste footprint. Heliyon 7:e06343. https://doi.org/10.1016/j.heliyon.2021.e06343

Chand S, Shastry CS, Hiremath S, Joel JJ, Krishnabhat CH, Mateti UV (2021) Updates on biomedical waste management during COVID19: the Indian scenario. Clin Epidemiol Glob Heal 11:100715. https://doi.org/10.1016/j.cegh.2021.100715

Chen Y, Ding Q, Yang X, Peng Z, Xu D, Feng Q (2013a) Application countermeasures of non-incineration technologies for medical waste treatment in China. Waste Manag Res 31(12):1237-1244. https:// doi.org/10.1177/0734242X13507314

Chen Y, Zhao R, Xue J, Li J (2013b) Generation and distribution of PAHs in the process of medical waste incineration. Waste Manag 33:1165-1173. https://doi.org/10.1016/j.wasman.2013.01.011

Chen WQ, Ciacci L, Sun NN, Yoshioka T (2020) Sustainable cycles and management of plastics: a brief review of RCR publications in 2019 and early 2020. Resour Conserv Recycl 159:104822. https://doi.org/ 10.1016/j.resconrec.2020.104822

CPCB (2016a) Biomedical Waste Management Rules, 2016 (Issue 1). https://cpcb.nic.in/uploads/Projects/Bio-Medical-Waste/Biomedical_Waste_Management_Rules_2016.pdf

CPCB (2016b) Design and construction requirements of the bio-medical waste incinerator (Revised Draft). https://mpcb.mizoram.gov.in/ uploads/attachments/8e7a5e8faed1ab9ad9ffc8d687bcc534/pages288-design-and-construction-of-bmw-incinerator.pdf

CPCB (2016c) Guidelines for management of healthcare waste as per biomedical waste management rules, 2016. https://tspcb.cgg.gov.
in/Shared\%20Documents/Guidelines\%20for\%20Management\% 20 of $\% 20$ Healthcare $\% 20$ Waste $\% 20$ Waste $\% 20$ Management $\%$ 20Rules, \%202016\%20by\%20Health\%20Care\%20Facilities.pdf

CPCB (2016d) Solid Waste Management Rules, 2016 (Issue REGD. NO. D. L.-33004/9933004/99). https://cpcb.nic.in/uploads/MSW/ SWM 2016.pdf

CPCB (2017a) Guidelines for co-processing of plastic waste in cement kilns. https://cpcb.nic.in/uploads/plasticwaste/Co-processing Guidelines_Final_23.05.17.pdf

CPCB (2017b) Guidelines for pre-processing and co-processing of hazardous and other wastes in cement plant. https://cpcb.nic.in/uploads/ hwmd/GUIDELINES-ON_CO-ProcessinginCement.pdf

CPCB (2019a) Annual report for the year 2018-19 on implementation of plastic waste management rules (Issue December).https://cpcb.nic. in/uploads/plasticwaste/Annual_Report_2018-19_PWM.pdf

CPCB (2019b) Annual report on biomedical waste management as per Biomedical Waste Management Rules, 2016 for the year 2019. https://cpcb.nic.in/uploads/Projects/Bio-Medical-Waste/AR_ BMWM_2019.pdf

CPCB (2020a) Generation of COVID-19 related biomedical waste in states/UTs. https://cpcb.nic.in/covid-waste-management/

CPCB (2020b) Scientific disposal of biomedical waste arising out of Covid-19 treatment compliance of BMWM rules. https:// greentribunal.gov.in/sites/default/files/news_updates/Status\% 20Report\%20in\%20O.A\%20No.\%2072\%20of\%202020.pdf

CPCB (2020c) Guidelines for handling, treatment and disposal of waste generated during treatment/diagnosis/quarantine of COVID-19 patients, (Issue March, 1). https://www.cpcb.nic.in/uploads/Projects/ Bio-Medical-Waste/BMW-GUIDELINES-COVID.pdf

CPCB (2020d) Guidelines for handling, treatment and disposal of waste generated during treatment/diagnosis/quarantine of COVID-19 patients, (Issue April, Revision 2). https://tspcb.cgg.gov.in/COVID19/ GPCB_Revision_2_CPCB_Guidelines_FOR_COVID_19.pdf

CPCB (2020e) Guidelines for handling, treatment and disposal of waste generated during treatment/diagnosis/quarantine of COVID-19 patients, (Issue June, Revision 3). https://tspcb.cgg.gov.in/COVID19/ Rev3\%20Guidelines \%20for\%20disposal $\% 20$ of $\% 20$ COVID $\%$ 2019\%20Waste_10_06_2020.pdf

CPCB (2020f) Guidelines for handling, treatment and disposal of waste generated during treatment/diagnosis/quarantine of COVID-19 patients, (Issue July, Revision 4). https://tspcb.cgg.gov.in/COVID19/ COVID-19\%20CPCB\%20Guidelines\%20(Revision-4)\%20for\% 20hanlding\%20of\%20COVID\%20BM\%20Waste\%2021-07-2020. pdf

Das AK, Islam MN, Billah MM, Sarker A (2021a) COVID-19 and municipal solid waste (MSW) management: a review. Environ Sci Pollut Res 28:28993-29008. https://doi.org/10.1007/s11356-02113914-6

Das AK, Islam MN, Billah MM, Sarker A (2021b) COVID-19 pandemic and healthcare solid waste management strategy —a mini-review. Sci Total Environ 778:146220. https://doi.org/10.1016/j.scitotenv. 2021.146220

Datta P, Mohi G, Chander J (2018) Biomedical waste management in India: critical appraisal. J Lab Phys 10:006-014. https://doi.org/10. 4103/jlp.jlp_89_17

Deepak A, Kumar D, Sharma V (2021) Developing an effectiveness index for biomedical waste management in Indian states using a composite indicators approach. Environ Sci Pollut Res. https://doi. org/10.1007/s11356-021-13940-4

Devi A, Ravindra K, Kaur M, Kumar R (2019) Evaluation of biomedical waste management practices in public and private sector of health care facilities in India. Environ Sci Pollut Res 26:26082-26089. https://doi.org/10.1007/s11356-019-05785-9

Gangwar HS, Ray PKC (2021) Geographic information system-based analysis of COVID-19 cases in India during pre-lockdown, 
lockdown, and unlock phases. Int J Infect Dis 105:424-435. https:// doi.org/10.1016/j.jiid.2021.02.070

Haque MS, Uddin S, Sayem SM, Mohib KM (2021) Coronavirus disease 2019 (COVID-19) induced waste scenario: a short overview. J Environ Chem Eng 9:104660. https://doi.org/10.1016/j.jece.2020. 104660

Ikram M, Zhang Q, Sroufe R, Ferasso M (2020) The social dimensions of corporate sustainability: an integrative framework including COVID-19 insights. Sustainability 12(20):8747. https://doi.org/10. 3390/su12208747

Ilyas S, Srivastava RR, Kim H (2020) Disinfection technology and strategies for COVID-19 hospital and bio-medical waste management. Sci Total Environ 749:141652. https://doi.org/10.1016/j.scitotenv. 2020.141652

Irfan M, Ikram M, Ahmad M, Wu H, Hao Y (2021) Does temperature matter for COVID-19 transmissibility? Evidence across Pakistani provinces. Environ Sci Pollut Res:1-15. https://doi.org/10.1007/ s11356-021-14875-6

Kampf G, Todt D, Pfaender S, Steinmann E (2020) Persistence of coronaviruses on inanimate surfaces and their inactivation with biocidal agents. J Hosp Infect 104:246-251. https://doi.org/10.1016/j. jhin.2020.01.022

Khoo KS, Ho LY, Lim HR, Leong HY, Chew KW (2021) Plastic waste associated with the COVID-19 pandemic: crisis or opportunity? J Hazard Mater 417:126108. https://doi.org/10.1016/j.jhazmat.2021. 126108

Klemeš JJ, Van Fan Y, Tan RR, Jiang P (2020) Minimizing the present and future plastic waste, energy and environmental footprints related to COVID-19. Renew Sust Energ Rev 127:109883. https://doi.org/ 10.1016/j.rser.2020.109883

Kulkarni BN, Anantharama V (2020) Repercussions of COVID-19 pandemic on municipal solid waste management: challenges and opportunities. Sci Total Environ 743:140693. https://doi.org/10.1016/j. scitotenv.2020.140693

Liu J, Vethaak AD, An L, Liu Q, Yang Y, Ding J (2021) An environmental dilemma for China during the COVID-19 pandemic: the explosion of disposable plastic wastes. Bull Environ Contam Toxicol 106:237-240. https://doi.org/10.1007/s00128-021-03121-x

Mohanan PV, Sangeetha V, Sabareeswaran A (2021) Safety of $0.5 \%$ hydrogen peroxide mist used in the disinfection gateway for COVID-19. Environ Sci Pollut Res. https://doi.org/10.1007/ s11356-021-15164-y

Nzediegwu C, Chang SX (2020) Improper solid waste management increases potential for COVID-19 spread in developing countries. Resour Conserv Recycl 161:104947. https://doi.org/10.1016/j. resconrec.2020.104947

Parashar N, Hait S (2021) Plastics in the time of COVID-19 pandemic: protector or polluter? Sci Total Environ 759:144274. https://doi.org/ 10.1016/j.scitotenv.2020.144274

Praveena SM, Aris AZ (2021) The impacts of COVID-19 on the environmental sustainability: a perspective from the Southeast Asian region. Environ Sci Pollut Res. https://doi.org/10.1007/s11356020-11774-0

Ramteke S, Sahu BL (2020) Novel coronavirus disease 2019 (COVID19) pandemic: considerations for the biomedical waste sector in India. Case Stud Chem Environ Eng 2:100029. https://doi.org/10. 1016/j.cscee.2020.100029

Rayani M, Rayani S, Najafi-Sharjabad F (2021) COVID-19-related knowledge, risk perception, information seeking, and adherence to preventive behaviors among undergraduate students, southern Iran. Environ Sci Pollut Res. https://doi.org/10.1007/s11356-021-14934$\mathrm{y}$

Rowan NJ, Laffey JG (2020) Challenges and solutions for addressing critical shortage of supply chain for personal and protective equipment (PPE) arising from coronavirus disease (COVID19) pandemic — case study from the Republic of Ireland. Sci Total
Environ 725:138532. https://doi.org/10.1016/j.scitotenv.2020. 138532

Rowan NJ, Laffey JG (2021) Unlocking the surge in demand for personal and protective equipment (PPE) and improvised face coverings arising from coronavirus disease (COVID-19) pandemic - implications for efficacy, reuse and sustainable waste management. Sci Total Environ 752:142259. https://doi.org/10.1016/j.scitotenv.2020. 142259

Roy N, Chaube R (2021) Environmental impact of Covid-19 pandemic in India. Int J Biol Innov 03:48-57. https://doi.org/10.46505/ijbi.2021. 3103

Rume T, Islam SMDU (2020) Environmental effects of COVID-19 pandemic and potential strategies of sustainability. Heliyon 6:e04965. https://doi.org/10.1016/j.heliyon.2020.e04965

Sangkham S (2020) Face mask and medical waste disposal during the novel COVID-19 pandemic in Asia. Case Stud Chem Environ Eng 2:100052. https://doi.org/10.1016/j.cscee.2020.100052

Sarkodie SA, Owusu PA (2020) Impact of COVID-19 pandemic on waste management. Environ Dev Sustain 23:7951-7960. https:// doi.org/10.1007/s10668-020-00956-y

Shammi M, Bodrud-Doza M, Towfiqul Islam ARM, Rahman MM (2020) COVID-19 pandemic, socioeconomic crisis and human stress in resource-limited settings: a case from Bangladesh. Heliyon 6:e04063. https://doi.org/10.1016/j.heliyon.2020.e04063

Shammi M, Behal A, Tareq SM (2021) The escalating biomedical waste management to control the environmental transmission of COVID19 pandemic: a perspective from two south Asian countries. Environ Sci Technol 55:4087-4093. https://doi.org/10.1021/acs.est.0c05117

Sharma HB, Vanapalli KR, Cheela VS et al (2020) Challenges, opportunities, and innovations for effective solid waste management during and post COVID-19 pandemic. Resour Conserv Recycl 162: 105052. https://doi.org/10.1016/j.resconrec.2020.105052

Shen Y, Yu S, Ge S, Chen X, Ge X, Chen M (2017) Hydrothermal carbonization of medical wastes and lignocellulosic biomass for solid fuel production from lab-scale to pilot-scale. Energy 118: 312-323. https://doi.org/10.1016/j.energy.2016.12.047

Shen M, Hu T, Huang W, Song B, Qin M, Yi H, Zeng G, Zhang Y (2021) Can incineration completely eliminate plastic wastes? An investigation of microplastics and heavy metals in the bottom ash and fly ash from an incineration plant. Sci Total Environ 779:146528. https:// doi.org/10.1016/j.scitotenv.2021.146528

Shibamoto T, Yasuhara A, Katami T (2007) Dioxin formation from waste incineration. Rev Environ Contam Toxicol 190:1-41. https://doi. org/10.1007/978-0-387-36903-7_1

Silva ALP, Prata JC, Walker TR et al (2020) Rethinking and optimizing plastic waste management under COVID-19 pandemic: policy solutions based on redesign and reduction of single-use plastics and personal protective equipment. Sci Total Environ 742:140565. https://doi.org/10.1016/j.scitotenv.2020.140565

Silva ALP, Prata JC, Walker TR et al (2021) Increased plastic pollution due to COVID-19 pandemic: challenges and recommendations. Chem Eng J 405:126683. https://doi.org/10.1016/j.cej.2020.126683

Singh N, Tang Y, Ogunseitan OA (2020a) Environmentally sustainable management of used personal protective equipment. Environ Sci Technol 54:8500-8502. https://doi.org/10.1021/acs.est.0c03022

Singh N, Tang Y, Zhang Z, Zheng C (2020b) COVID-19 waste management: effective and successful measures in Wuhan, China. Resour Conserv Recycl 163:105071. https://doi.org/10.1016/j.resconrec. 2020.105071

Tabish M, Khatoon A, Alkahtani S, Alkahtane A, Alghamdi J, Ahmed SA, Mir SS, Albasher G, Almeer R, al-Sultan NK, Aljarba NH, alQahtani WS, al-Zharani M, Nayak AK, Hasnain MS (2020) Approaches for prevention and environmental management of novel COVID-19. Environ Sci Pollut Res 28:40311-40321. https://doi. org/10.1007/s11356-020-10640-3 
Thind PS, Sareen A, Singh DD, Singh S, John S (2021) Compromising situation of India's bio-medical waste incineration units during pandemic outbreak of COVID-19: associated environmental-health impacts and mitigation measures. Environ Pollut 276:116621. https:// doi.org/10.1016/j.envpol.2021.116621

United Nations Environment Programme (UNEP) (2012) Compendium of technologies for treatment/destruction of healthcare waste, Japan. https://wedocs.unep.org/bitstream/handle/20.500.11822/8628/ IETC_Compendium_Technologies_Treatment_Destruction_ Healthcare_Waste.pdf? sequence $=3 \&$ is $-\overline{\text { lllowed }}=\mathrm{y}$

Vanapalli KR, Sharma HB, Ranjan VP, Samal B, Bhattacharya J, Dubey BK, Goel S (2021) Challenges and strategies for effective plastic waste management during and post COVID-19 pandemic. Sci Total Environ 750:141514. https://doi.org/10.1016/j.scitotenv.2020. 141514

WHO (2018) National Health-Care Waste Management Plan-Guidance Manual. https://www.who.int/water_sanitation_health/ medicalwaste/en/guidancemanuall.pdf
WHO (2020) Water, sanitation, hygiene, and waste management for SARS-CoV-2, the virus that causes COVID-19. https:/www.who. int/publications/i/item/water-sanitation-hygiene-and-wastemanagement-for-the-covid-19-virus-interim-guidance

Worldometers 2021, COVID-19 pandemic, https://www.worldometers. info/coronavirus/

Yousefi M, Oskoei V, Jonidi Jafari A, Farzadkia M, Hasham Firooz M, Abdollahinejad B, Torkashvand J (2021) Municipal solid waste management during COVID-19 pandemic: effects and repercussions. Environ Sci Pollut Res 28:32200-32209. https://doi.org/10. 1007/s11356-021-14214-9

Zimmermann K (2017) Microwave as an emerging technology for the treatment of biohazardous waste: a mini-review. Waste Manag Res 35(5):471-479. https://doi.org/10.1177/0734242X16684385

Publisher's note Springer Nature remains neutral with regard to jurisdictional claims in published maps and institutional affiliations. 